\title{
Bir Melodramla Tarih Yazmak Mümkün Mü?
}

\section{Is It Possible to Write History with a Melodrama?}

\author{
Nilay Ulusoy ${ }^{a^{*}}$ \\ ${ }^{a}$ Doç. Dr., Bahçeşehir Üniversitesi İletişim Fakültesi, Sinema ve Televizyon Bölümü, 34488, İstanbul/Türkiye \\ ORCID: 0000-0002-2176-7003
}

\section{MAKALE BILGİSI}

\section{Makale Geçmişi:}

Başvuru tarihi: 12 Aralık 2018

Düzeltme tarihi: 05 Ocak 2019

Kabul tarihi: 14 Ocak 2019

\section{Anahtar Kelimeler:}

Tarih Yazımı ve Sinema,

Alevilik,

Melodram

\section{ARTICLE INFO}

\section{Article history:}

Received: 15 December 2018

Received in revised form: 05 January 2019

Accepted: 14 January 2019

\section{Keywords:}

Cinema and Historiography,

Alevis,

Melodrama

\section{ÖZ}

Hayden White "Tarihyazımı ve Historiophoty" makalesinde tarihsel filmlerin tarihi olayları aktarabilecek güçlü bir araç olduğunu söyler. Robert A. Rosenstone da White'ın görüşünden yola çıkarak tarihsel dünyanın yaratımında görüntünün ve sesin gücünün, tarihçinin tıkandığı noktada tarihi anlatmada yeni bir firsat olduğunu söyler. Ancak sinema ile tarih yazımının olanakları ve sınırları da ayrı bir tartışma konusudur. Tarihi filmlerde tarihi belgelere ne kadar başvurulması gerektiği kadar kullanılan dil ve filmin türü de önem kazanmaktadır. Çalışmada Alevi bir kız ile Sünni bir oğlanın melodramatik aşk hikâyesini anlatının merkezine alarak 1980 Mayıs- Temmuz aylarında gerçekleşen Çorum Olayları'ndan 12 Eylül Darbesi'ne kadar uzanan yaklaşık dört aylık bir süreci aktaran 2010 yapımı "Saklı Hayatlar"ın, türsel özellikleri, teması, anlatı yapısı, karakter oluşumu gibi özellikleri ele tarihyazımı yapması irdelenecektir.

\begin{abstract}
A B S T R A C T
Hayden White in his article "Historywriting and Historiophoty" underlines that films are capable of reflecting historical incidents. In the same way, Robert A. Rosenstone underlines the fact that the possibilities of sound and image provide the basis for a representation of historical facts when the historian feels limited within words. It should be kept in mind that, possibilities and limitations of both cinema and history writing are another topic of debate. In historical film, the filmic language and genre conventions are as critical as the narrative's relevance to historical documents and facts. In this study, the film"Hidden Lives" which narrate a bitter love story of an Alevi girl and Sunni boy, is also elaborate the period of four months in between Çorum Incidents and 12 September Military coup; will consider through its theme, narration, characterisation with several features of melodramatic modality.
\end{abstract}

\section{Giriş: Tarih Sinemacının Yazdığı Mıdır?}

Popüler tarihyazımının aslında çok satan romanlar, popüler televizyon dizileri ya da uzun metraj filmler gibi kurmaca anlatı teknikleri yoluyla tarihsel olayları temsil etme pratiği olduğunu söyleyebiliriz. Özellikle tarihsel hikâyelerin içerdikleri görsel zenginlik; kahraman, çatışma gibi klasik dramaturjinin ve öyküleme sürecinin en temel öğelerinin tarihte neredeyse hazır malzeme olarak bulunması, sinema için tarihi başvurulan bir kaynak durumuna sokmuştur (Erkılıç, 2014, s. 18). Robert A. Rosenstone (1988) film üzerinden tarih anlatısının tür ve dil ile şekillendiğini; tarihsel dünyanın doğasını yönetmenin hikâyeyi hissedişi doğrultusunda seçtiği türler tarafından anlatıya sunulduğunu belirtir (s. 1180). 2010 yapımı "Saklı Hayatlar"ın hikâyesi,
Linda Williams'ın (1998) deyimiyle; popüler sinemanın bir öğesi olan ve anlatısı bolca acı ve aksiyon içeren bir kip olan melodramatik anlatı ile şekillenmiştir (s.51). Film yönetmen Ahmet Haluk Ünal'ın deyişiyle Alevilerin saklı hayatlarını anlatan (A.H. Ünal, kişisel görüşme, Ocak 12, 2013); Türkiye Sineması'nda Alevi-Sünni mezhep ayrımını açık bir şekilde konu eden çok az sayıdaki filmden biri olarak, Çorum Olayları 'ndan başlayarak 12 Eylül Darbesine varan yaklaşık üç aylık bir dönemi ele almaktadır. "Saklı Hayatlar" biri Alevi, diğeri Sünni ailelerden gelen iki gencin imkânsız aşk öyküsünü yukarıda bahsedilen tarihsel dönemde gerçekleşen olaylar eşliğinde ișlemiştir. Makalede, film genelde melodram türü özelde ise Türk Sinemasında melodram kipinin özellikleri üzerinden analiz edilmeye çalışılacaktır. Böylece bir melodram filminin tarihteki belli

\footnotetext{
* Sorumlu yazar/Corresponding author

e-posta: nilay.ulusoy@comm.bau.edu.tr
} 
bir dönemi ele alışı; ana akım filmlerle tarihyazımı kıstasları üzerinden değerlendirilmeye çalışılacaktır.

\section{Geçmişin Temsili Tarihin Özeti}

Tarihi metinleri edebiyat kuramları üzerinden okumayı öneren Hayden White, "Geçmişe erişimimiz yalnızca metinler aracılığıyla mümkündür, geçmiş geçmiştir ve tamamen erişilmesi mümkün değildir. Tarihi metinler sadece tarihçilerin yaptığı okumalarla; birçok metne, belgeye dayanarak geçmişe dair ortaya koydukları bilgilerdir yani tarihyazımı aslında anlatıcı olarak tarihçinin bakış açısının bir dişavurumudur" der. Yine White'a göre, bu metinler sözel kurgulardır ve tarihsel dönemin farz edilen somutluk ve erişilebilirliği, aynı edebiyatçının üzerinde çalıştığı metinlerin bağlamının kendisi gibi, bu bağlamı çalışan tarihçinin de kurgu yeteneğinin ürünüdürler (akt. Uysal, 2011, s. 9). White (1988) "tarihin ve tarihsel olaylara ait düşüncelerimizin görselik ve film söylemi ile temsil edilmesi" olarak açıkladığı "historiophoty" kavramını ortaya koyarken; filmi tarih yazımında bir araç olarak tanımlar. White için görüntü ve sesin alfabesi ile öykü anlatma aracı olan filmler de diğer tüm tarih yazan araçlar gibi bir anlatı olarak içinde yaratıcısının yorumunu barındırırlar (s. 1193). H.G. Walsh (1977) da tarihi olayların çoğu zaman esnek ve tartışmalı oldukları için ancak bir anlatının katkısı ile anlam kazandıklarını söyler. Geçmişe ait gerçeklikler böylece üretildikleri toplumun bu gerçeklikleri ürettiği süre içerisinde etkili olurlar (s. 55). Rosenstone (2006) da bu düşünürlerle aynı görüşü paylaşır ancak bir bilim dalı olarak tarihin; edebiyat ve sinemaya inat her şeyi tüm objektifliği ile vermek iddiasından vazgeçmediğini söyler. Oysa tarihin dili; kurmaca barındırdığı için diğer tüm anlatıların dili gibi muğlaktır. Öncü çalışması "Tarih Nedir?"de Edward Hallett Carr (1990) "tarihsel vakaların” bir büyükelçinin mektubu ya da imzaladığı bir belge gibi somut bilgiler olduğunu ancak bu bilgiye bir anlam yüklemek için onun bir "anlatı ile sarmalanması" gerektiğini söyler. Ancak Carr sözlerine tarihsel vakaların, geçmişe dair hikâyelerle "sarmalandığında" artık bilimsel tarafsızlıklarını kaybedeceklerini de ekler (s. 16). Rosenstone ise sinemanın bu bilimsel tarafsızlık konusundaki kısıtlamalara karşı hassasiyet barındırdığını ve tarihsel olayları daha iyi kaydedebilmek için önemli soruları daha korkusuzca sorabildiğini belirtir. Geçmişi ete kemiğe büründüren sinemacının aynı tarihçi gibi günümüzde de var olan problemlerin geçmişte nasıl problem haline geldiklerini incelemek amacında olduğunu belirten Rosenstone; filmin tarihle rekabet etmesi için mutlaka geçmişi tarih yazınından farklı, yeni bir biçimde anlatması gerektiğini söyler. Kısaca filmin kendi estetiğini kullanarak izleyiciyi zaten bildiğini düşündüğü şeyler konusunda yeniden düşünmeye ikna etmesi gerektiğini belirtir (s. 115-118).

Geçmişi unutturmamak ve yeniden üstünde düşündürmek için tarihçinin bilimsel olarak derlediği ve teyit ettiği bilgileri kamusal alanda tartışmaya sunmak gerekir. Ortak bellek ve

\footnotetext{
${ }^{1}$ Rosenstone'un (2018) belirlediği diğer iki kategori ise "belge olarak tarih" ve "deney olarak tarih"tir. Yazar söz konusu çalışmasında, "dram olarak tarih anlatısını" sinema filmleri öyküler anlatmaya başladığı zamandan beri üretilmekte olan" tüm filmleri tanımlamak üzere kullanmıştır. Belgelenebilir kişilere veya olaylara dayanan filmlerin yanı sıra; merkezi tema ve karakterleri kurgusal olarak, tarihsel dekorları ve öyküsü özgün bir hikâyeyi
}

teknolojinin birbiriyle yakından ilgili olduğu düşünüldüğünde, kameranın 20. Yüzyılda tarihi materyali topluma ulaştırmada ve saklamada önemli bir yeri olduğunu söylemek gerekir. Kisaca sinema unutmanın riskleri doğrultusunda çalışan bir sanattır (Kurasawa, 2004, s. 29). Sinema güçlü bir kitle iletişim aracı olarak bu tartışmayı açabilecek, geçmişte muhtemel olmuş olanın kurgusunu yapabilecek güçtedir. Raack (1983) filmi, geçmişin canlılığını yeniden yaratabilme kapasitesi sayesinde tarihyazımını en üst seviyede gerçekleştirebilecek araç olarak tanımlar (s. 416). Ancak Erkılıç'a (2014) göre, geçmişin yeniden yaratılmasında sinemacının önemli bir unsura dikkat etmesi gerekir. Sinemacı geçmişi tekrar kurgularken tarihi olaylara bu günün penceresinden bakmamalıdır. Sinema diliyle geçmiş yeniden yaratılırken durumlar, olaylar ve karakterler kendi zaman dilimleri göz önüne alınarak değerlendirilmelidir (ss. 15,16).

Bunun sonucu olarak sinemadan geçmişin birebir aynısını üretmesi beklenemez. Film, yazı dilinden de farklı olarak tarihi evrim, aşk, imkânsızlık gibi genel ifadeler üzerinden tanımlayamaz. Bunun yerine görüntüler aracılığı ile özetleme ve sentezleme yoluna gider. Filmler geçmişin anlamını, görüntülü tasvirlere dayanarak sembolleştirir (Ersoy, 2016). "Saklı Hayatlar” 12 Eylül Darbesinden önceki üç aylık süreci Rosenstone'un (2018) tarihsel filmi ayrıştırdığ 3 temel kategoriden "drama olarak tarih anlatısı" çerçevesinde işlemektedir (s. 164-177). Daha sonra bu kategoriyi "ana akım drama" olarak adlandırmıştır. Ana akım sinemasının başı ortası sonu belli olan belirli olaylar dizisini, belli karakterler aracılığıyla anlattığı hikâyeleri barındıran "drama olarak tarih anlatısı" filmlerinde genellikle öykünün ilk başında sıradan birer insan olarak tarif edilen bazen tarihte gerçekten yaşamış bazen de anlatıcı tarafından kurgulanmış karakterler daha sonra karşılaştıkları zorluklara göğüs gererek birer kahramana dönüşürler. Bu filmlerdeki karakterler genellikle tanıdık ama hikâye geliştikçe; sorunlar gün yüzüne çıktıkça sertleşen, inatçı bir hale gelen karakterlerdir. $\mathrm{Bu}$ dönüşümleri hikâyedeki değişimi yaratacak çatışmalar için imkân sağlar. Bu kahramanların kişisel problemleri tarihsel çatışmaların içinde, sanki tarihsel problemlerin bir parçasıymışçasına verilir. Bu yolla söz konusu filmler, izleyicinin kafasında herhangi bir şüphe uyandırmadan geçmişe dair kesin bir neden sonuç ilişkisi verirler (Rosenstone, 2001, s. 53-56).

Hayden White (1985) da öykülendirme ile tarihyazımının; olgulara dayanan bilgileri belli bir kurgu içerisinde anlatma eğiliminde olduğunu söyler. Bu kurgulama edebi pek çok tekniği içinde barındırır (s. 82).Film yarattığı karakterler ile geçmişle bu gün arasında bir bağ kuran bir anlatı olarak bize geçmişe dair bir tahmin sunar. Lubomir Doležel, bizim gerçek dünyamızın diğer olanaklı dünyalarla çevrelendiğini ve kurmaca dünyaların fiili dünyamızın "olanaklı dünyaları" olduğunu söyler. Çünkü bu kurmaca olanaklı dünyalar gerçekleşmemiş, fiiliyata geçmemiş olanaklı kişiler, durumlar, olaylardan oluşurlar. Kurmaca dünyalar gerçek

barındıran filmler de "dram olarak tarih anlatısı" yapan filmlerin kapsamı içerisindedir (s.164). "Saklı Hayatlar" bu ikinci kategoride yer alan bir film olarak özgün hikâyesini 1980 yılına uyarlamış, Alevi Sünni çatışmasına odaklanan imkânsız aşk ilişkisini; acıklı, kestirmeci, çapraşık olaylarla dolu, sonuçta ahlak dersi veren melodramatik kipte bir hikâye olarak tanımlamıştır (Arslan, 2005, s. 16). 
dünyaların taklidi değildir, gerçek dünya ile ilişki kuran olası dünyalardır. Tarihyazımında hiç yaşamadığı ya da tarihsel olaya dâhil olmadığı ispatlanan bir isim, tarihsel dünyanın dışına çıkarılır. Kurmaca dünyada ise bu türden sınırlamalar olmadığı gibi tarihsel kurmaca şahsiyetler hikâyeye eklenebilir ya da hikâyeler bu şekilde tarihi yorumlayanın ki sinema söz konusu olduğunda bu yönetmen ve senaristtir, tarihsel olaya dair kurduğu gerçekliğe destek verecek hikâye ve atmosferin kurulmasına olanak sağlar (akt. Uysal, 2011, s.14). "Sakl1 Hayatlar"; 12 Eylül Darbesinin hemen öncesindeki çatışma ortamını, toplumun ayrışmasını, anlatısal hareketi zitlıklar üzerinden veren melodram türünü kullanarak mutlak sona varan ve tamamı kurmaca karakterlerden oluşan bir hikâye üzerinden şekillendirir. Türkiye'de süregelen en temel mezhepsel ayrışmayı, bu ayrışmanın nedeniyle art arda yaşanan şiddet olaylarının en çok ön plana çıktığı tarihi dönemde, imkânsız bir aşk ilişkisi üzerinden sembolleştirir ve 1980 yılının mayıs ile eylül ayları arasında geçen sürece dair bir tahminde bulunur.

Ancak Doležel, Hayden White'ın tarihyazımı ve kurmaca yaratımını eşitleyen bakışını tam anlamıyla kabul etmez ve bir "hakikat değeri" kavramından söz eder. Tarihi metinlerin hakikat değerini gözeterek" gerçek dünyanın geçmişinin modelini" yarattığını belirtir. Oysa kurmaca metinler hakikat değerini tarihsel metinler kadar gözetmezler. Hakikate benzeyen olası dünyalar yaratırlar (a.g.e. s.15). Rosenstone (1992) anaakım filmlerde hikâyenin giriş, gelişme ve sonuç şeklinde ilerleyen kapalı yapılar olmasının tarihi olayları farklı boyutları ile anlatmayı imkânsız kıldığını kabul eder. Ancak bunun bu popüler filmlerin tarihyazımındaki becerilerini azaltmadığını, yazılı tarih geleneğinden uzaklaşılsa dahi tarihsel kesinliği yine de aynı şekilde sağlayabildiklerini belirtir (ss. 507-509). Thompson and Bordwell (2008)e göre anlatı sinemasındaki duygusal deneyim hikâyenin inandırıcılığını arttırır (s.69). Atalay’a (2018) göre de tarihteki acıları anlatan melodram filmleri görüntünün gücü yardımıyla izleyiciye tarihsel gerçeklikler yerine geçmişin yönetmende yarattığı hissiyatı anlatır ve bu şekilde bir öznellik yaratır, böylece izleyiciyi tarihin şahidi mertebesine çıkarırlar (s.40). "Saklı Hayatlar"da yukarıda bahsedildiği şekilde; imkansız aşkı temel alan popüler Yeşilçam anlatısını yine 12 Eylül öncesindeki siyasi karışıklık dönemine ve Alevi ve Sünni mezhep çatışmasına kurmaca bir evrende bağlayarak, izleyiciyi romantik ve masum bir nostaljik evrene yönlendirir.

\section{Alevilerin Dramı Sünnilerin Trajedisi Hepimizin Melodramı}

Linda Williams (1998), melodramın içerdiği pathos ve aksiyon ile seyircinin ilgisini çektiğini; onların motivasyonlarını manipüle etme kabiliyetine sahip olduğunu söyler. Melodramlar izleyiciye yoğun duygular deneyimleme imkânı verirler (s.51-52). Bu sebeple Christine Gledhill (1987) melodramları bir çeşit "duyarlılık" kipi olarak tanımlar (s. 5). Akbulut'a (2011) göre melodramın metinlerarası niteliği, onu eklektik, melez, hayalet bir tür, estetik bir rejik, bir imgelem tarzı olarak tanımlamaya

\footnotetext{
2 Sinemasal tarihin ne olduğunu tanımlayan türsel özellikleri ortaya koymaya çalışan Robert Brent Toplin, bu filmlerin aşk ilişkilerini tarihsel olayların merkezinde olmadan, hikâyelerin içine yerleştirdiğini söyler (akt. Erkılıç, 2014, s. 51). "Saklı Hayatlar"da ise aşk ilişkisi merkezdedir, tarihi olaylar gerçekleşirken hikâyenin
}

götürür. Akbulut'un Vasudevan'dan aktardığı şekilde bu imgelem tarzı, her kültürde belli noktalarda yerel ile birleşir ve işler. Batılı bir form olan melodram, yerel olan ile harmanlanır ve o kültüre ait melodram kipini yerelleştirir (s.12). Yeşilçam Sinemasının ise kendine özgü kalıpları, kuralları vardır. Yeşilçam melodramları masalsı formları ile abartıya açıktırlar ve bu sayede popüler kültürdeki herkesin aşina olduğu masallara ve Türk edebiyatındaki sözlü âşık hikâyelerine bağlanırlar. Berna Moran bir çeşit romans niteliği taşıyan bu âşık hikâyelerinin; temel olarak kalıplaşmış, ortak bir olay örgüsü etrafında geliştiklerini ifade eder. Buna göre; genç kız ve genç erkek arasındaki aşk hikâyesinin doğuşu, genç âşıkların kötü karakterlerin yaptıkları yüzünden ayrı düşmeleri, birbirlerine tekrar kavuşabilmeleri için verdikleri mücadele, hikâyenin kötü son yani ölüm veya mutlu son yani evlilikle sona ermesi süreci söz konusu âşık hikâyelerinin ortak anlatı noktalarıdır. Melodramların merkezinde bulunan ve olmazsa olmaz diyebileceğimiz esas oğlan, esas kız ve kötü adamdan oluşan üçlü yap1, bu anlamda geçmişten gelen bir anlatı geleneğini takip eder (Arslan, 2005, s. 52).

"Saklı Hayatlar"da melodramların kalıplaşmış öykü modellerine çok benzer bir şekilde aşk; hayatın merkezindeymişçesine verilir ve hikâye kalıplaşmış iyi-kötü, varsıl-yoksul gibi ikilikler üzerinden ayrılan ilişki ağları ile aktarılır². Bu filmler; kötü bir karakterin tamamen iyi, masum karakterleri; bu karakterlerin arasında yaşanacak masum aşkları, nefret, entrika ve kin nedeniyle kurban etme hikâyelerini anlatır (Singer, 2001, s. 39). Rosenstone'un (2018) da belirttiği gibi “drama türünde tarihi filmler” tarihin bireylerin hikâyesi olduğunun altını çizer (s. 167). "Saklı Hayatlar"da anlatı iyiler ve kötülerin arasında geçen temel bir aşk anlatısı biçiminde görülür. İyi ve kötü arasındaki çatışma birbirini seven iyilerin ayrılığı ve birleşmesi ekseninde yaşanır. Bu heteroseksüel arzu ile tüm melodram anlatılarında itici gücü aşk olur. İyi karakterler saflıkları, dürüstlükleri ile aşkı hak ettiklerini izleyiciye yansıtırlar. Anlatının eksenindeki karakterler mutlaka iyidir (Akbulut, 2011, s. 16). Nilgün Abisel (1994) de yerli filmlerin olay örgüsünü dört ana başlıkta inceler. Önce genç kız ve erkek karşılaşır ve ilk bakışta aşık olurlar (s. 92). Filmde Nergis (Ceren Hindistan) gecekondu mahallelerinde halka sağlık hizmeti sunan bir tıp öğrencisi, Murat (Yusuf Akgün) ise sol görüşlü bir derneğe bağlı olarak 12 Eylül'ün hemen öncesindeki siyasi mücadeleyi fotoğraf ile belgelemeye çalışan, bunun yanı sıra yasa dışı yollardan çocuk işçi çalıştıran işletmelerle mücadele eden bir genç olarak iyileri temsil etmektedirler. Nergis'in ailesi Murat'ların kiracısı olarak eve taşınınca iki genç karşılaşır ve aşık olurlar. İyilerin yani Murat ve Nergis'in bir araya gelmesini engelleyen kötüler tek bir kimlikte verilir: Filmin ilk sahnesinde gecekondularda gönüllü olarak çalışan Nergis ve arkadaşlarını kaba bir şekilde kovan ve film süresince her firsatta bir engel ve tehlike olarak karşımızda beliren polisler. Öte yandan ana hikâyeyi oluşturan aşk ilişkisini bozmaya çalışan diğer kötü ise Murat'ın emekli bir polis olan babası Tevfik (Ahmet Mümtaz Taylan) olur. Böylece

ana teması olan iki gencin arasındaki aşk ilişkisinin evreleri izleyici tarafından takip edilir. Aşkın hikâyenin merkezine alınması da melodram kipinin yukarıda bahsedilen özelliklerinden biri olarak karşımıza çıkmaktadır. 
Abisel'in ikinci kategorisi de gerçekleşir ve sevgililer entrika ya da sosyo ekonomik koşullardan değil ama mezhepsel farklılıklar yüzünden ayrı düşerler (a.g.e.). Yeşilçam melodramlarında karakterlerin iyi ya da kötü olmaları davranış ve tutumları kadar görüntülerinden de anlașılır. "Saklı Hayatlar"da polis üniforması bir "tehlike sinyali" gibi izleyene sunulur. Polislerin Nergis ve arkadaşlarını zorla durdurmalarının hemen ertesinde, Murat'in aile evi gösterilir. Tevfik ve babaanne Emine (Zerrin Sümer) Çorum olayları ile ilgili radyo haberini dinlemektedirler. Kamera duvardaki resimlere yönelir. Ölmüş dedenin resminin hemen solunda kamera sabitlenir, çünkü burada artık dünyada olmayan anne ile polis üniformalı Tevfik'in yan yana oturdukları bir aile resmi durmaktadır. Böylece Tevfik'in de hikâyenin üzerine oturduğu aşk ilişkisini bozacak, örseleyecek bir karakter olduğu görülür.

Yönetmen A. Haluk Ünal filmin merkezinde önyarg1 kavramının durduğunu, önyargıların insanları nasıl felakete sürükleyeceğini anlatmak istediklerini söyler. $\mathrm{Bu}$ açıdan bakıldığında Tevfik aslında kötü bir baba değildir, sadece Aleviliğe karşı önyargılıdır. Sokakta, mahallede, iş yerinde iyi birer insan olarak bilinen fakat toplumda bazı hassas konular devreye girdiğinde; ötekini düşman olarak görebilen bir kişidir Tevfik (A.H. Ünal, kişisel görüşme, Ocak 12, 2013). Bu nedenle ilk başta iyi bir insan olarak tanıdığımız Tevfik, filmin ilerleyen sahnelerinde değişir ve toplumda var olan önyargıları taşıyan bir karakter haline döner. Hikâyede problemler çıktıkça daha inatçı olan Tevfik, ilişkide bulunduğu diğer karakterleri de kendi karakter gelişimi doğrultusunda dönüştürür. Öncelikle oğlunu üniversiteden mezun olduğu gibi bir devlet memuriyetine ya da en azından bir fotoğrafçı dükkânı açarak işe başlatma çabası ile bunlar için tanıdıklarını araya sokması ki Murat'ın tutku ile bağlı olduğu fotoğraf sanatını da para kazanılmayacak bir meslek olarak görmektedir; Murat'ın politik görüşlerinden hoşlanmaması ve sürekli oğlunu bu alanda tenkit etmesi hatta zamanla zor kullanması, Alevi olduğunu öğrendiği andan itibaren oğlunun Nergis ile ilişkisine karşı çıkması, Nergis'in ailesini evden kovması, yaptığını savunmak için Çorum Olayları ve Alevilikle ile ilgili olarak toplumda var olan tüm önyargıları bir çırpıda dile getirmesi ve iki sevgiliyi ayırmak için tanıdığı sağ görüşlü gençlere Nergis'i kaçırtmayı planlaması; polisin yanı sıra Tevfik'in bu aşk hikâyesindeki diğer bir kötü olarak karşımıza çıkmasını doğurur. Ancak önyargı sadece Tevfik ya da babaanne Emine'de değildir. Zeynep kızı Nergis'i Murat ile yol ağızında öpüşürken gördüğünde olduğu yere yığılır, bu iki sevgilinin ayrılacağına dair ilk işarettir; ikisi de ayrı yollara giderler. Zeynep önce "Faşizme karşı omuz omuza" yazılı duvarın önünde düşünür, ağlar; daha sonra eve döndüğünde Nergis'i hırpalar ve ona "Bize yapılanlar hiç mi umurunda değil? Biraz canın yanaydı o Yezid'in oğluyla oynaşır mıydın?" diyerek ilişkiyi bitirmesi için adeta emir verir. Aslında "Saklı Hayatlar"da Yeşilçam melodramlarında zengin fakir ikiliği üzerine yerleştirilen hikâyenin dönüşmüş bir şeklini görürüz. Bu farklılık iki sevgilinin bir araya

\footnotetext{
3 Linda Williams (2000) melodramlarda filmin kadın karakterlerinin ataerkil düzende onlara atfedilen anne, eş, terk edilmiş aşık karakterleri içerisinde daima pasif olarak konumlandırıldığını belirtir. Bu pasif konumlandırma zaman zaman kadın karakterlerin ağlamak, acı çekmek şeklinde "aşırı duygular" içerisinde gösterilmesi ile daha yoğun bir hal alır (s. 219). Yukarıda da belirtildiği üzere erkeğin eksikliği ile çile çeken kadınlar nesneye
}

gelmesini imkânsız hale getirir. Filmde bu ayrım mezhepsel farklılığa dönüştürülmüştür. İstanbullu ve iki katlı apartmanın üst katında oturan ev sahibi Sünni Murat ile taşradan İstanbul'a yeni göçmüş ve alt kata yerleşmiş Alevi Nergis'in aşk1; popüler melodramlarda olağanüstü yollardan sınıf atlayarak sevdiğine kavuşan karakterlerin aşkından çok daha imkânsız olarak verilmektedir. Böylece Abisel'in (1994) sevgililerin çeşitli zorlu ilişkilere sürüklenerek birbirlerinden ayrı kalması kalıbı da filmde gerçekleşir (s. 92). Uzlaşmacı ve mutlu sonla biten melodramlardan farklı olarak yönetmen Haluk Ünal, Alevi Sünni ayrımının, önyargıların kaynaklık ettiği ruh halinin günümüzde de devam ettiğinin altını çizmek için "aynı binayı paylaşıp, aynı eve çıkamayan" iki karakterin hikâyesini anlatmak istediğini belirtmiştir (A. H. Ünal, kişisel görüşme, Ocak 12, 2013).

Pek çok popüler anlatıda olduğu gibi melodramlarda başlangıçta bir denge unsuru vardır. Bu denge bozulur ve sonunda yeniden ama farklı bir şekilde tekrardan kurulur (Abisel vd., 2005, s.24). Çorum'dan kaçarak İstanbul'a gelen, korkudan Amasya'dan geldiklerini söyleyerek bir Sünni mahallesine yerleşen ve kendilerini saklayan Nergis'in ailesi; Murat'ın ailesi için hem iyi bir komşu olmuştur ve hem de Tevfik' in emekli maaşına katkı olacak ek gelir kaynağıdırlar. Tüm gün evde sıkılan babaanne için küçük kız kardeş Gülcan (Irmak Öztürk) bir can yoldaşı olmuştur. Melodramlarda daima kutsanan, her ne pahasına olursa olsun korunan aile "Saklı Hayatlar"da aslında eksiktir. Almanya'da çalışan baba evde yoktur, filmin ilk sahnelerinde babanın duvardaki resminin aynadaki aksini görürüz ama anne Zeynep (Laçin Ceylan) canla başla babanın yokluğunu hissettirmemek için çabalamaktadır, bu uğurda Çorum'da yaşadıklarını İstanbul'da okuyan kızına açıkça anlatmaz. Yeşilçam filmlerindeki annelerin bir benzeri olan Zeynep güçlü, dayanıklı, kararlı ve sadıktır (Abisel, 1994, s. 81). Filmin açılış sahnesinde Nergis'ten gizli olarak sırtındaki aynadan morlukları kontrol ederken görürüz, Nergis odaya geldiğinde toparlanır ve konuyu değiştirir. Onun etkilenmesinden, korkmasından ya da sinirlenip yanlış bir hareket yapmasından korkmaktadır, ne de olsa "kadın başlarına yaşamaktadırlar". Melodramlardaki ana kadın karakterlerin "kaçınılmaz bir özveri figürü" oldukları ve bunun da geleneksel rol modellerini pekiştirici bir platform olduğu ileri sürülür. Karşıtlıklar, eksiklikler kadar kadınların fedakârlıkları da dramatik özelliklerin yaslandığ Melodramatik anlatımlarda erkeksiz olmak bir eksiklik olarak belirtilir. Hatta bu eksikli "çile çekmek" şeklinde ifade edilir (Akbulut, 2011, s. 16). Nergis'in ailesindeki eksiklik Murat'ın Nergis'in sevgilisi olarak; Tevfik'in ise ilk başlardaki babacan, düşünceli erkek karakter olarak karşımıza çıkması ile geçici olarak giderilir, bu dengeye Zeynep'in fedakâr ve güçlü anne karakteri de eklenir. Murat'ın da annesi yıllar önce ölmüştür. Babaanne Emine aile içerisinde annenin yokluğunu hissettirmeyen sağduyunun, şefkatin sembolü olarak durmaktadır, Yeşilçam filmlerinde sık rastlanan dindar, doğru yolu bilen

giden yolu, yani evlilikle ödüllendirilmeyi beklerler. Nergis tıp okuyan genç bir kadın olarak pasif kalmayı ret eden, çile çekmek yerine çabalamayı, ayakta durmayı deneyen, annesi ve Tevfik gibi otorite figürlerinin zorlamalarına itiraz eden bir karakter olarak filmin girişinde resmedilse de; filmin sonunda sevgilisi kollarında öldüğ̈̈nde sokağın ortasında çaresizce oturup "çı̆̆lık çı̆̆lığa" ağlamaktan ve acı çekmekten kurtulamaz. 
ninelerdendir. Tevfik Murat'ı işe girmesi için zorladığında karşı çıkar. Nergis'in ailesinin Alevi olduğu öğrenildiğinde mahallelinin evlerine saldırmasını engeller. "Saklı Hayatlar"da Tevfik genellikle Yeşilçam melodramlarında resmedilen mütevâzi ailelerdeki babaların hepsi gibi bir fedakârlık figürü olarak ön plana çıkmaktadır (Abisel, 1994, s. 80-81). Murat'a çok düşkündür, oğlu onun geleceğidir. Yaşlı annesinin yetişemediği yerde anne rolünü oynar, oğluna kıyamaz, yemeğini sofrada önüne koyar. Murat'a eve geri dönmesi için yalvardığında "başka bir kadının eline düşme diye hayatıma kimseyi sokmadım, bu mudur karşılığı?" diyerek hem Murat'ın eksikliğini duyduğu annesinin yerine geçmeye çalıştığına hem de fedakârlık yaptığına dikkat çeker. Nergis'in ailesinde babanın yokluğunun yarattığı güvensizlik ile Murat'ın ailesinde annenin yokluğunun yarattığ 1 hüzün; iki gencin mutlu sonla bitmesi mümkün olmayacak aşkının yanı sıra aslında filmde dengenin de kısa süre içerisinde bozulacağına dair bir hissiyatı daha filmin ilk başında yaratır. Üstelik filmin ilerleyen sahnelerinde Murat'in babası Tevfik'in politikayı bırakıp işe girmesine ya da Nergis'ten ayrılmasına dair 1srarlarına evinden ayrılarak karşılık vermesi de yani eksik de olsa aileyi dağıtması dengeyi bozan diğer önemli unsurlardandır. Türk Sinemasında korunması, yüceltilmesi gereken, temel bir kurum olan ailenin yıkılması bir "suçtur" ve filmin sonunda cezalandirılır. Abisel'in (1994) yerli filmlere uyguladığı şemanın son şıkkı olan "yanlışlıklar düzelir ve evlenirler ya da ölürler" kategorisi de "Saklı Hayatlar"da gerçekleşmiş olur (s. 92).

Daha önce belirtildiği üzere melodramlarda kötü karakterler hikâyenin başından itibaren gerek davranışları gerek ise görüntüleri ile kendilerini belli ederler. İyiler onlarla savaşır ve filmlerin sonunda daha ilk başta var olan ahlaki ve toplumsal düzen yeniden sağlanır. Bu durumda "Saklı Hayatlar"'ın sonunda Murat'1n babasının yaptığı plan sonucunda Nergis'i kurtarmak uğruna ölmesi yani AleviSünni aşkının mutlu bir sona ulaşamaması; Alevi ailenin İstanbul'un merkezindeki Sünni mahallede barınamayacağını anlayarak Alevilerin yaşadığı gecekondu mahallesine taşınması yani Nergis'in ailesinin şehire, merkeze yerleşme, saklı da olsa çoğunluk ile birlikte yaşama arzusunun ve mücadelesinin yenilgi ile sonuçlanması; var olan toplumsal düzenin filmin sonunda kutsanmasa da yeniden kurulmasını doğurmaktadır. Ancak yukarıda bahsettiğimiz klasikdramatik anlatılardaki denge, filmin sonunda ikinci defa kurulduğunda ilkine benziyor olsa da il baştakinden farklı bir denge şeklinde ortaya çıkar (Abisel vd. s. 24). Nergis ve ailesi kendileri gibi Alevilerin olduğu İstanbul'un dış(1na) mahallelerine taşınmış, Tevfik'in mahallesi "temizlenmiş" eski haline dönmüştür ancak bu sefer yeri doldurulamaz büyük bir kayıp vardır; Murat ölmüştür. Linda Williams (2000) melodram filmlerinin temel özelliklerinden bahsederken; bu filmlerde "yoğun duygularla yüklü, aşırılığa kaçan mazoşistik fantazinin her zaman "çok geç!" bir zamansallık sunduğunu" belirtir. Tevfik, Emine ve tüm mahalleli mezhepsel önyargılarını yıkmak için artık "çok geç" kalmışlardır, bir umut olarak yeşeren aşk sona ermiş ve mutluluk ve bir açıdan toplumsal huzur için firsat kaçırılmıştır. Ancak yine Williams'a göre

\footnotetext{
${ }^{4}$ Erkılıç'ın (2014) sınıflandırmasındaki diğer kategoriler; tarihsel tüm öğelerin kurmaca olduğu "Tarihe yaklaşımda fantastik öğelerin öne çıktığı filmler” ve tarihsel olaylara bir sav ile yaklaşarak,
}

“Çok geç kalma”nın yarattığı çaresizlik ve bu ruh halinin oluşturduğu "aşırı duygusallık" o kadar yoğundur ki; bu durum melodramları "sadece ağlatan hikâyeler" olmaktan çıkararak gerçekleri anlamak açısından güçlü birer aktarıcı durumuna sokarlar (ss. 219-220).

\section{Sonuç: "Bir Acıyı Yok Etmenin Yollarından Biri de Onu Görünür Kılmaktır"}

Türk Sinemasının anlatımında melodramatik kipin önemi ve izleyici açısında etkisini göz ardı etmek mümkün değildir. Türk Sineması için bir türden çok her filmin içine işleyen bir estetik ve kültürel bir "hayalet usul, biçim ya da yöntem" olan melodramatik kip, Türk Sinemasında hemen hemen her filmde, her türde ve anlatıda kendini konumlandırır ve bu filmlerin anlattıkları hikâyeler izleyicinin alıştığı, tanıdığı hikâyeler olarak ilgi görürler (Arslan, 2011, s. 136). İki genç arasındaki aşk ilişkisinden 12 Eylül Darbesi'nin hemen öncesinde gerçekleşen olayları iki genç arasındaki aşk ilişkisini merkez alarak işleyen "Saklı Hayatlar", Senem Duruel Erkılıç'ın (2014) Türk Sinemasında farklı yaklaşımlarla çekilen tarihi filmler sınıflandırmasında ${ }^{4}$ "Tarihi gerçeklerden yola çıkarak çekilen filmler" kategorisine uymaktadır. Zamanın ve mekânın olduğu kadar o mekânda ve zamanda gerçekleşen çatışmanın da hikâyede açık bir şekilde verildiği bu filmlerde gerçek ve kurmaca iç içedir (s. 84)

Ancak melodramlar söz konusu olduğunda tarihi yorum ve ifade biçimi ikircikli bir durum alabilmektedir. Melodramlarda mutlaka her şeyin tekrar eski düzenine geri döneceğine dair verilen ahlaki mesaj; toplumdaki hızlı değişimlerin karşısında yeni dünyanın ahlaki ve toplumsal değerlerini yeniden tanımlar ve toplumun eskiye bağglılığını kaybetmediğini yansıtmaya çalışır. Her şeyin izleyiciye "gerçekmiş" gibi göründüğü melodramlar geleneklerin devamlılığını gündelik hayatlarında sağlayamayan modern insan için duygusal bir tüketim mecrası olarak karşımıza çıkarlar (Oskay, 2000, s.333). Söz konusu açıdan "Saklı Hayatlar"da işlenen Alevi Sünni ayrımcılığı, sosyal ve ekonomik bağlamı ikinci plana atılarak imkânsız bir aşk ekseninde izleyiciye sunulmaktadır. Öte yandan Robert Rosentone'a (2018) göre "ana akım dramalar filmler bireyleri tarihsel sürecin ön saflarına yerleştirerek onların kişisel problemlerinin çözümünün, tarihsel problemlerin çözümüyle yer değiştirmesine yol açarlar. Kısaca kişisellik; film tarafindan işaret edilen çoğunlukla zor ya da çözülmeyen sosyal problemlerden kaçmanın bir yolu haline gelir" (s. 167). "Saklı Hayatlar" filminde günümüzde hala toplumda devam eden mezhepsel önyargılar ve bunun tarihte aralıklarla ortaya çıkardıkları şiddetli çatışmalar; iki genç arasındaki aşk ilişkisinin kötü bir şekilde son bulması ve duyulan pişmanlık, hüzün, acı ile ifade edilmektedir.

Linda Williams (1998), mizansen, hareket, oyunculuk ya da anlatısal motivasyon ile kurulan gerçekçi sinemasal etkinin aslında melodram etkisini güçlendirdiğini belirtir (s. 42). Rosenstone ana akım dramaların öncelikle tarihsel olayları kişiselleştirdiğini, dramatize ettiğini ve bu şekilde geçmişi duygularla ifade ettiğini söyler. Bu filmler aynı zamanda "geçmişin görünümünü” vermek amacıyla; binaların,

tarihsel tez geliştiren "Tarihe bir savla yaklaşan filmler"dir (a.g.e. s. 83-84). 
çevrenin, kostümün geçmiş zamana uygun görüntülerini de kullanırlar (akt. Erkılıç, 2014, s. 44). "Saklı Hayatlar" izleyiciye tanıdık gelen Yeşilçam melodramlarının devamı sayılabilecek imkânsız aşk teması, bu aşkı el ele diz dize yaşayan iki genç ana karakteri, mekânsal kurgu açısından 1970'li yılların İstanbul'unu anımsatan Arnavut kaldırımı sokakları, mütevâzi mahalleleri, bahçe içinde ahşap iki katlı evlerin duvarlara asılı kaybedilmiş aile büyüklerinin resimleri ile dolu, gün boyu radyo dinlenilen salonları, bu salonlarda namaz kılan neneleri, politik hareketin içinde topluma yeni bir yön vermeye çalışan genç karakterleri, karakterlerin 1970'lerin giyim kuşamını yansıtan kıyafetleri, saç kesimleri, politik söylemlerle dolu konuşmaları ile 12 Eylül Askeri Darbesi'nin hemen öncesinde var olan siyasal çatışmayı, mezhepsel gerginlikleri aktarırken aynı zamanda izleyiciye güçlü bir arka plan verir.

Marc Ferro (1995) "Potemkin Zırhlısı" (Sergei Eisenstein, 1925) ile ilgili olarak "eğer Eisenstein bu film üzerinden geçmiş temsilini yapmamış olsaydı tarihe dair bu budanmış versiyon bile belki de insanların belleğinden yitip gitmiş olacaktı" der (s. 88). Edward Carr ise her kuşağın tarihini gözden geçirmez ise bu tarihin yavaş yavaş öleceğini ve toplumsal oluşumun dramatik iniş çıkışları yerine geleneksel söylencelerin geçeceğini söyler (akt. Erkılıç, 2014, s.25). Bu tanımlar göz önüne alındığında, Saklı Hayatlar'ın geçmişi sürekli var olan temsil şekilleri ile yeniden inşa ettiğini öne sürerken; aynı zamanda "film imajları ile saklanan tarihin asla solmadığg”" da göz önüne alınmalıdır (Anton Kaes, 1990, s. 114). Ayrıca tarihi gerçeklerin ortada açık seçik bir şekilde durmadığı, tarihçiler kadar sinemacıların da bu gerçekleri gömülü olduğu yerden çıkarmayı amaç edindikleri de dikkate alınmalıdır. Bu açıdan A. Haluk Ünal'ın filmi ile daha önce Türkiye Sinemasında dile getirilmemiş bazı olay ve olgulara "Bir acıyı yok etmenin yollarından biri de onu görünür kılmaktır" diyerek dikkat çekmesi önemlidir (Tosun, 2013). Irk, din, dil ayrılığından doğan bir nefret ve önyargının temsilini yapmanın herkes tarafından basit ya da üstün ya da "kesin olarak doğru" şeklinde tanımlanabilecek bir yolu yoktur. Sadece geçmişi bir şekilde izlenilir kılan tarihi filmler, tarihteki olayları tekrar görünür kılarak, izleyiciye geçmişi, bu günü ve yarını düşündürmeye yönlendirir. Tarihyazımı bir bilim dalı olarak teyit edip bütünleştirmeyi hedeflese de tarihi hikâyelemeyi amaçlayan tüm sanatsal türler ebedi bir sorgulama ile muhtemel olanın var olduğu "yaratıcı belirsizlik" alanında gezinir, tarihyazımından farklı sezgisel yükü olan bir bilgiyi paylaşır. Sinema açısından ele alırsak izleyici ile tarihin aktörleri arasında kurulan "empati", tarihyazımından farklı bir güce sahip olarak, tarihi bireylerin açmazları, hevesleri, toplulukların ortak güdüleri, travmalı üzerinden daha çok düşünmeye itebilir (Ersoy, a.g.e.). Melodram her yerde, her şartta ve her anlatıda var olabilir. İyi-kötü, masum-günahkâr, yoksul-zengin gibi karşıtlıkların çatışmalarından çıkıp

\footnotetext{
${ }^{5}$ Burada Christine Gledhill'in melodramların gerçekçilik ile ilişkisi üzerine söylediklerine değinmek gereklidir. Gledhill'e (1987) göre günlük hayatın zorluklarından ve problemlerinden yola çıkan melodramların (s.22); gerçekçilik ile farklı bir ilişkisi, özdeşlemesi vardır. Melodramlar "şeyleri" iki farklı şekilde sunarlar; "şeylerin" nasıl olduğu kadar, nasıl olması gerektiğinin de altını çizerler. Böylece maddi dünyanın gündelik gerçekliğinin ve yaşanan gündelik deneyimlerin limitinden sıyrllarak kimlik, benlik ve insanlığa ait değerler gibi pek çok anlamın estetik temsilini bize sunarlar (akt. Williams, 1998, s.48). Vivian Sobchack (1996) da,
}

heyecan, ağlama, gerilim, eğlence gibi çeşitli değer duyguları izleyicilere aktarır. Bu sundukları ile izleyicinin ortak paydada buluştuğu değerleri onlara yeniden hatırlatır, hayata temelden bağlı olan toplumun çoğulluğuna seslenir (Arslan, 2005, ss. 112-113). Rosenstone'un (2018) deyimi ile bu filmler geçmişin gerçek(miş gibi) ${ }^{5}$ dünyasına açtıkları bir pencere ile bağlanır (s. 166). "Saklı Hayatlar" tanıdık bir imkânsız aşk hikâyesinden Alevi Sünni mezhepsel ayrımını ve bu ayrımın taşıdığı ön yargıları eleştirmiş ve bu eleştiriyi yaparken de Türkiye'nin yakın tarihinde gerçekleşmiş Çorum Olaylarını, Türk Sinemasında ilk defa arka planına alarak sunmuştur.

\section{Kaynakça}

Abisel, N. (1994). Türk Sineması Üzerine Yazılar, Ankara: İmge Yayınevi.

Abisel, N., Arslan, U.T., Behçetoğulları, P., Karadoğan, A., Öztürk, S.R. \& Ulusay, N. (2005). Çok Tuhaf Çok Tanıdık. İstanbul: Metis.

Akbulut, H. (2008). Kadına Melodram Yakışır - Türk Melodram Sinemasında Kadın Imgeleri, İstanbul: Bağlam Yayıncilık.

Akbulut, H. (2011). Yessilçam'dan Yeni Türk Sinemasına Melodramatik Imgelem, İstanbul: Hayalperest Yayınevi.

Arslan, S. (2005). Melodram, L\&M Yayınları: İstanbul.

Arslan, S. (2011). Cinema in Turkey: A New Critical History-Türkiye'de Sinema: Yeni Eleştirel Tarih,, Oxford University Press: Oxford, New York.

Atalay Gürgen, D. (2018). Historiography of World War II in Contemporary American Cinema-Günümüz Amerikan Sinemasında II. Dünya Savaşı Tarihyazımı, Cambridge Scholars: New Castle upon Tyne.

Bordwell, D. \& Thompson, K. (2008). Film Art: An Introduction-Film Sanatı: Giriş. USA:University of Wisconsin Press.

Carr, E. H. (1990). What is History-Tarih Nedir? London: Penguin Books.

Elsaesser, T. (1996). "Subject Positions, Speaking Positions, from Holocaust, our Hitler, and Heimat to Shoah and Schindler's List-Shoah ve Shindler'in Listesinden Heimat, Hitler, Holocaust'tan Bahsedebilme ve Konu Edebilme", Persistence of History, Cinema Television and Modern Event-Modern Olaylarin, Televizyon ve Sinemada Tarihsel Devamlılığl, ed: Vivian Sobchack, Routledge: New York, London, s. 145-183.

tarihteki büyük ve travmatik olayların film karakterlerinin günlük hayatına eklemlenmesinin bu filmlere yeni, gerçekçi bir tarih bilinci kattığını ve bunun da alternatif bir tarihyazımı oluşturabildiğini söyler. Böylece tarihsel filmlerde var olan karakterlerin hayatlarında tecrübe ettikleri bu "büyük olaylar"; izleyicinin kişisel bağ kurabileceği, "inandırıcı" bir hal alırlar. Hatta bu etki o kadar güçlüdür ki izleyici bu olayları "şimdi yaşıyormuşçasına" hissederek izler ve bu olayları yaşayan film karakterleri ile ortaklık kurarlar (s. 5). 
Erkılıç, S. D. (2014). Türk Sinemasında TARIH ve BELLEK, Ankara: De-Ki Basım Yayım.

Ersoy, A. (2016). "Tarihle Çeşitli Şekillerde Halleşmek Modern İnsan için Varoluşsal Bir Gereklilik Olmalı", Tarihyazımı ile Kurmacanın Ilişkisi Üzerine, http://t24.com.tr/k24/yazi/sorusturma-tarih,881, son izlenme tarihi: 15.10.2018.

Ferro, M. (1968). "1917: History and Cinema-Tarih ve Sinema", Journal of Contemporary History, Vol:3, No:4, 1918-1919: From War to Peace, s. 45-61.

Ferro, M. (1995). Sinema ve Tarih. Çev: Turhan Ilgaz, Hülya Tufan, Kesit Yayıncılık: İstanbul.

Gledhill, C. (1987). 'The Melodramatic Field: An Investigation-Melodramatik Alan: Bir Araştırma', C. Gledhill (ed.), Home is Where the Heart is: Studies in Melodrama and the Woman's Film-Ev Kalbin Neredeyse Oradadır: Kadın Filmleri ve Melodramlar Üzerine Çalışmalar, BFI: London, ss. 5-39.

Kaes, A. (1990). History and Film: Public Memory in the Age of Electronic Dissemination-Tarih ve Film: Elektronik Yayılım Döneminde Toplumsal Hafiza, History and Memory, Vol:2, No:1, s. 111-129.

Kaya, F. (2013). Representation of Precarious Labor and City Outskirt in the Late Cinema of Turkey-Güvencesiz Emek ve Kent Kıyılarının Son Dönem Türkiye Sinemasında Temsili, Basılmamış Yüksek Lisans Tezi, İstanbul: Bahçeşehir Üniversitesi.

Kırel, S. (2005). Yeşilçam Öykü Sineması, Babil Yayınları: İstanbul.

Kurasawa, F. (2004). Cinema, or an Art of Urban Memory in an Age of Forgetting-Unutma Çă̆ında Sinema ya da Kentsel Hafiza Sanat, https://public.journals.yorku.ca/index.php/public/article/vie w/30355/27883, son izlenme tarihi: 22.11.2018.

Oskay Ü. (2000). Tek Kişilik Haçlı Seferleri, İstanbul: İnk1lap Kitabevi.

Raack, R. J. (1983). "Historiography as Cinematography: A Prolegomenon to film work for historians", The Journal of Contemporary History, 18 (3). ss. 411-438

Rosenstone, R. A. (Nisan 1985). "Genres, History and Hollywood. A Review Article-Türler, Tarih ve Hollywood", Comparative Studies in Society and History, Vol.27, No. 2,s. 367-375.

Rosenstone, R. A. (1988). "History in Images/History in Words: Reflections on the Possibility of Really Putting History onto Film-Görüntüde Tarih/Dilde Tarih: Tarihi Sinemaya Gerçekten Uyarlamanın İmkânları ", The American Historical Review, Vol.93, no.5, ss.1173-1185.

Rosenstone, R. A. (1992). “JFK: Historical Fact / Historical Film-JFK: Tarihsel Gerçek/Tarihsel Film”. The American Historical Review, 97 (2). ss. 506-511.

Rosenstone, R. A. (2001). "The Historical Film: Looking at the Past in a Postliterate Age-Tarihsel Film: Sözel Dönem
Sonrası Geçmișe Bakmak", The Historical Film: History and Memory in Media-Tarihsel Film:Medyada Tarih ve Hafiza, der: Marcia Landy, New Brunswick, New Jersey: Rutgers University Press, ss. 50-66.

Rosenstone, R.A. (2006). History on Film/Film on HistoryFilmde Tarih/Tarihte Film, Pearson-Longman: London, New York.

Rosenstone, R. A. (2018). "Gerçek Tarih Olarak Tarihsel Film”, (Çev. Y. Lüleci), Sinesine, 9 (1), 159-181.

Singer, B. (2002). Melodrama and Modernity-Early Sensational Cinema and its Context-Melodram ve Modernite: Erken Duygusal Sinema ve İçeriği, Columbia University Press: New York.

Sobchack, V. (1996). "History Happens-Tarih Olur", The Persistence of History: Cinema, Television, and the Modern Event- Tarihin Israrl: Sinema, Televizyon ve Modern Olay, (Ed.) Vivian Sobchack, New York, London: Routledge.

Sobchack, V. (1997). "The insistent Fringe: Moving Images and Historical Consciousness. History and Theory". 42. (6). Theme issue 36: Producing the Past:Making Histories Outside and Inside the Academy, ss. 4-20

Tosun, A. (2013). “Alevilerin Dramı Sünnilerin Trajedisidir",

http://arsiv.tsa.org.tr/uploads/documents/bu filmin basrolu nde istanbul_var 4373/837_2.pdf, son izlenme tarihi: 25.04.2018.

Ulusoy, N. (2013). "Alevi Revival in Turkish Fictional Cinema After 2000's-2000'ler Sonrasında Türk Kurmaca Sinemasında Alevi Uyanışı”, Humanities and Social Sciences Review, 2(3): 293-311.

Uyanık, Z. "Son Dönem Türk Sinemasında Alevi Kimliğinin Görünümü”, $\quad$ http://dergipark.gov.tr/download/articlefile/155170, son izlenme tarihi: 13.10.2018.

Uysal, Z. (2011). "Giriş: Edebiyatın Omuzundaki Melek", Edebiyatın Omzundaki Melek Edebiyatın Tarihle İlişkisi Üzerine Yazllar, İletişim Yayınları: İstanbul, ss.7-24.

Walsh, W. H. (1977). "Truth and Fact in History Reconsidered-Tarihte Hakikat ve Gerçeklik", History and Theory. 16 (4). ss. 53-71.

White, H. (1985). "Historical Text as Literary ArtifactTarihsel Metin ve Edebi Olgusu", Topics of Discourse Essays in Cultural Criticism-Kültürel Elestiri üzerine Denemelerin Söylemleri, Baltimore, London: The Johns Hopkins University Press, ss. 82-84.

White, H. (1988). "Historiography and Historiophoty". Americal Historial Review, 93 (5). ss. 1193- 1198.

Williams, L. (1998). "Melodrama Revisited- Melodrama Yeniden Bakış", (ed.) N. Brown, Refiguring American Film Genres: Theory and History-Amerikan Film Türlerini Tekrardan Ele Almak: Teori ve Tarih, Berkeley and Los Angeles: University of California Press, ss. 42-89.

Williams, L. (2000). "Film Bodies: Gender, Genre and Excess-Film Yapıları: Cinsiyet, Tür ve Așır1lık", Film and Theory: An Anthology-Film ve Teori: Bir Anatoloji, (Ed.) Robert Stam \& Toby Miller, Massachusetts, Oxford: Blackwell Publishers, ss.207-222. 

